\title{
Ecological characteristics of Simulium breeding sites in West Africa
}

Robert A. Cheke $\mathrm{a}^{*}$, Stephen Young ${ }^{\mathrm{a}}$, Rolf Garms ${ }^{\mathrm{b}}$

\section{ABSTRACT}

Twenty-nine taxa of Simulium were identified amongst 527 collections of larvae and pupae from untreated rivers and streams in Liberia (362 collections in 1967-71 \& 1989), Togo (125 in 1979-81), Benin (35 in 1979-81) and Ghana (5 in 1980-81). Presence or absence of associations between different taxa were used to group them into six clusters using Ward agglomerative hierarchical cluster analysis. Environmental data associated with the preimaginal habitats were then analysed in relation to the six clusters by one way ANOVA. The results revealed significant effects in determining the clusters of maximum river width $(\mathrm{P}<$ 0.001), water temperature $(\mathrm{P}<0.001)$, dry bulb air temperature $(\mathrm{P}<0.001)$, relative humidity ( $\mathrm{P}<0.01$ ), altitude $(\mathrm{P}=0.001)$, type of water (on a range from trickle to large river, $\mathrm{P}<$ 0.001), water level $(\mathrm{P}<0.001)$, river bed type $(\mathrm{P}<0.01)$, slope $(\mathrm{P}<0.001)$, current $(\mathrm{P}<$ 0.001), vegetation $(\mathrm{P}<0.001)$, light conditions $(\mathrm{P}<0.001)$, discharge $(\mathrm{P}<0.001)$, length of breeding area $(\mathrm{P}<0.001)$, environs $(\mathrm{P}<0.001)$, terrain $(\mathrm{P}<0.001)$ and the supports to which the insects were attached $(\mathrm{P}<0.01)$. When four non-significant contributors (wet bulb temperature, river features, height of waterfall and depth) were excluded and the reduced data-set analysed by principal components analysis (PCA), the first two principal components 
(PCs) accounted for $87 \%$ of the variance, with geographical features dominant in PC1 and hydrological characteristics in PC2. The analyses also revealed the ecological characteristics of each taxon's pre-imaginal habitats, which are discussed with particular reference to members of the Simulium damnosum species complex, whose breeding site distributions were further analysed by canonical correspondence analysis (CCA), a method also applied to the data on non-vector species.

Keywords: Environmental variables, cluster analysis, PCA, CCA, Simulium damnosum complex

\section{Introduction}

Blackflies of the genus Simulium, which includes vectors of onchocerciasis such as the $S$. damnosum complex, lay eggs in flowing water where their larvae and pupae develop before eclosion. As different species are found in differing categories of streams and rivers, egg-laying females presumably respond to cues in their habitats when selecting oviposition sites together with factors such as oviposition pheromones released by females that have already laid eggs in a particular micro-habitat (McCall, 1995, McCall et al., 1997). For the $S$. damnosum complex the environmental cues include river size, river discharge rate, $\mathrm{pH}$, 
conductivity and temperature (Quillévéré et al., 1976, 1977; Cheke, 2012) but to date no multivariate analyses of breeding site environmental variables for this important group of onchocerciasis vectors have been conducted, although some Central American vectors have been studied using canonical correspondence analysis (CCA) (Millest et al., 1999). Similar studies in the tropics involving both principal components analysis (PCA) and CCA have been conducted on the blackfly faunas of Thailand (Srisuka et al., 2015) and Malaysia (Ya'cob et al., 2016a,b), with related studies using presence-absence data published for Brazil (Couceiro et al., 2014) and Algeria (Chaoui Boudghane-Bendiouis et al., 2014).

Here we present analyses of data collected in Benin, Ghana, Liberia and Togo, consisting of information on the presence or absence of larvae and / or pupae of Simulium spp. in riverine breeding sites in relation to environmental characteristics of the sites surveyed in order to establish trends and relationships between the species' occurrences and the environmental variables. Regarding the vectors of onchocerciasis amongst the species identified, it is hoped that the results will help to identify the habitat types in which they may be found breeding and, in some cases, indicate the species likely to be present in a particular river. In addition, they may assist in predicting likely changes in geographical distributions in relation to climate change.

\section{Methods}

During field work in Liberia in the $1967-1971$ period, all rivulets, streams and rivers in which Simulium spp. could breed were examined for the presence of larvae and pupae and, in many cases, traps were placed to collect Crustacea which might harbour pre-imaginal 
stages of phoretic species of blackflies, as described by Garms (1974). In Benin, Ghana and Togo only riverine sites that might harbour breeding $S$. damnosum s.l. were prospected as part of research programmes and routine activities organised by the WHO Onchocerciasis Control Programme (OCP), but restricted to the period 1979-81 in rivers yet to be treated with insecticides. Most of these sites were accessed by helicopter and environmental data were collected simultaneously when pre-imaginal stages of Simulium were searched for. The environmental data included measurements and subjective assessments of habitat characteristics (Table 1). Regrettably, no data on $\mathrm{pH}$, dissolved oxygen concentrations or conductivity were obtained in sufficient amounts to be included in the analyses. For the multivariate analyses described below, missing values for environmental variables were replaced by their overall mean values.

Presence or absence associations between different taxa were used to group them into six clusters using Ward agglomerative hierarchical cluster analysis programmed in R. Environmental data associated with the pre-imaginal habitats were then analysed in relation to the clusters by one way ANOVA. When four non-significant contributors (wet bulb temperature, river features, height of waterfall and depth) were excluded, the reduced data-set was analysed by both principal components analysis (PCA) and canonical correspondence analysis (CCA; Ter Braak, 1986; Legendre \& Legendre 1998, calculated as described by Oksanen et al., 2016). Regression and ordination are combined in CCA to generate a gradient that optimizes the distinctions between the species' distributions on ordination axes which are constrained as linear combinations of environmental variables (Ter Braak, 1986). Thereby, CCA results in an ordination diagram of samples, species and environmental variables optimally displaying how community composition varies in relation to the environment. 


\section{Results}

Data were collated from 527 sites in Liberia (362 collections in 1967-71 \& 1989), Togo (125 in 1979-81), Benin (35 in 1979-81) and Ghana (5 in 1980-81). Garms (1974) provided maps of the Liberian sites and of the geographical distributions within the country of each species that he identified. See also Garms \& Vajime (1975) for the $S$. damnosum complex in Liberia. The sites in Benin, Ghana and Togo were all amongst those depicted in maps published by Garms et al. (1982, 1983, 1989), Cheke \& Garms (1983) and Cheke et al. (1987). Samples included representatives of the following taxa, followed in parentheses by the countries in which they were found listed by their initial letters $(B=$ Benin; $G=$ Ghana; $L=$ Liberia; $T=$ Togo), and by notes: Simulium damnosum sensu lato (B,G,L,T); S. damnosum Theobald 1903 sensu stricto (B,G,L,T,); S. sirbanum Vajime \& Dunbar 1975 (B,T; not recorded in Liberia in the samples for this study but the species is known to occur there, see Garms et al. 1991); $S$. yahense Vajime \& Dunbar 1975 (L,T); S. sanctipauli Vajime \& Dunbar 1975 sensu lato (B,G,L,T); S. sanctipauli sensu Post 1996 (subsumed within S. sanctipauli s.l. in the analyses) (B,G,L,T); S. sanctipauli Djodji form Surtees, Fiasorgbor, Post \& Weber 1988 (G,T); S. soubrense Vajime \& Dunbar 1975 sensu Post 1986 (subsumed within S. sanctipauli s.l. in the analyses); S. soubrense Beffa form Meredith, Cheke \& Garms 1983 (B,T); S. squamosum (Enderlein 1921) cytotaxonomic description by Vajime \& Dunbar 1975 (B,G,T); S. tridens Freeman \& de Meillon 1953 (B,L,T); S. ruficorne Macquart 1838 (T); S. loutetense Grenier \& Ovazza 1951 (L); S. alcocki Pomeroy 1922 (L,T); S. garmsi Crosskey 1969 (L); S. djallonense Roubaud \& Grenier 1943 (L); S. johannae Wanson 1947 (L); S. liberiense Garms 1973 (L); S. schoutedeni Wanson 1947 (L,T); S. unicornutum Pomeroy 1920 (B,G,L,T); S. 
blacklocki de Meillon 1930 (L); S. cervicornutum Pomeroy 1920 (G,L,T); S. kenyae de Meillon 1940 (B,L,T); S. adersi Pomeroy 1922 (B,G,L,T); S. ovazzae Grenier \& Mouchet 1959 (L, phoretic on freshwater crabs Liberonautes latidactylus and mayfly larvae of the genera Elassoneuria and Afronurus); S. berneri Freeman 1954 (L, phoretic on freshwater crabs Liberonautes latidactylus and mayfly larvae of the genera Elassoneuria and Afronurus); S. lumbwanum de Meillon 1944 (L, phoretic on freshwater crabs Liberonautes latidactylus and mayfly larvae of the genera Elassoneuria and Afronurus); S. manense Elsen \& Escaffre, 1976 (L, listed as S. debegene de Meillon 1934 by Garms 1974); S. futaense Garms \& Post 1966 (L); S. colasbelcouri Grenier \& Ovazza 1951 (L); S. hargreavesi Gibbins 1934 (B,T); S. bovis de Meillon 1930 (T, Togo was not listed for this species by Adler \& Crosskey (2016), but pupae were collected in Togo in R. Anie, 12.07.1979, and larvae and pupae in R. Na, 23.08.81).

Because the majority of the Liberian samples were collected and identified before the description of different cytospecies of the $S$. damnosum complex, we were unable to assign all such samples to taxa lower than $S$. damnosum s.l. except in a few cases such as in the St. Paul and Yah rivers where subsequent identifications provided strong indications of the taxa likely to be present. Also, for Liberia, we used a category of S. sanctipauli s.l. as we could not be sure which of the various members of the $S$. sanctipauli sub-complex reported in Liberia had been present at the sites and times of our collections, especially since different forms may occur sympatrically (Güzelhan \& Garms 1991).

Figure 1 shows results of the cluster analysis using the entire data-set, stopped at a level of six clusters and shows how the various species were associated within these different clusters. Cluster 2 contained species only found in Liberia and, similarly, very few of the species in 
clusters 5 and 6 ever occurred there. A one-way ANOVA was then performed for each river variable against the cluster codes. The results revealed significant effects in determining the clusters of maximum river width $(\mathrm{P}<0.001)$, water temperature $(\mathrm{P}<0.001)$, dry bulb air temperature $(\mathrm{P}<0.001)$, relative humidity $(\mathrm{P}<0.01)$, altitude $(\mathrm{P}=0.001)$, type of water (on a range from trickle to large river, $\mathrm{P}<0.001)$, water level $(\mathrm{P}<0.001)$, river bed type $(\mathrm{P}<0.01)$, slope $(\mathrm{P}<0.001)$, current $(\mathrm{P}<0.001)$, vegetation $(\mathrm{P}<0.001)$, light conditions $(\mathrm{P}<0.001)$, discharge ( $\mathrm{P}<0.001)$, length of breeding area $(\mathrm{P}<0.001)$, environs $(\mathrm{P}<0.001)$, terrain $(\mathrm{P}<$ $0.001)$ and the supports to which the insects were attached $(\mathrm{P}<0.01)$.

Four of the river variables (wet bulb temperature, river features, height of waterfall and depth) were non-significant contributors. These were then excluded and the reduced data-set analysed by principal components analysis (PCA). The first two principal components (PCs) accounted for $87 \%$ of the variance, with geographical features dominant in PC1 and hydrological characteristics in PC2 (Fig. 2A), which can be related to the species clusters on the PCA axes depicted in Fig. 2B.

Means and standard errors of the values for each of the measured environmental variables are listed in Table 2 according to species. Table 3 provides mean values of the subjective habitat assessments (1-5 scales in all cases, except 1-3 for light conditions and terrain) according to Simulium taxon.

When CCA was applied to data only for the various members of the S. damnosum complex involved then the CCA1 (x) axis was dominated by temperature effects and the CCA2 (y) axis mainly by hydrological characteristics of the rivers (Fig. 3A). With this in mind, interpretation of the CCA plot for the vector species (Fig. 3B) is instructive as it clearly shows the separation of the Liberian $S$. sanctipauli sub-complex according to high river 
discharge rates and other hydrological parameters as the top-most along the CCA2 axis and $S$. yahense according to temperature far to the right on the CCA1 axis. Other separations follow CCA2 according to hydrology, with close alignments of $S$. sirbanum, the Beffa form of $S$. soubrense and $S$. damnosum s.str., species which are often sympatric, separated from $S$. squamosum which is grouped not far from the Djodji form of S. sanctipauli (the two were often sympatric before the latter was extirpated, see Cheke et al. 2008).

CCA results for the environmental variables of the non-vector species have CCA1 again dominated by temperature with hydrological features notable in CCA2 (Fig 4A). Species isolated in the ordination diagram, apparently lacking non-vector congeners with similar ecological requirements, include $S$. tridens, $S$. kenyae, $S$. futaense, $S$. berneri, $S$. adersi and $S$. hargreavesi, while most of the remainder are clumped near to each other (Fig. 4B).

\section{Discussion}

Given the 17 environmental variables that were statistically significant contributors to the separation of the clusters, it is clear that breeding site choice in the Simuliidae is governed by a multiplicity of factors. The results also provided evidence for substantial niche separations between species, as shown by the means of variables according to species (Tables $2 \& 3$ ) and the results of both the PCAs and the CCAs. The first two principal components (PCs) accounted for $87 \%$ of the variance, with geographical features dominant in PC1 and hydrological characteristics in PC2. In the CCA, temperature dominated CCA1 and hydrological features CCA2. 
Ever since the first description of different members of the Simulium damnosum complex by Vajime \& Dunbar (1975), it was realised that they had different ecological adaptations, typically considered as being forest for the $S$. sanctipauli sub-complex and S. yahense, and savanna for $S$. damnosum s.str., S. sirbanum and $S$. sudanense (not encountered in this study), with S. squamosum mostly found in forested highlands and S. soubrense in forest-savanna mosaic habitats. In addition the $S$. sanctipauli sub-complex was usually in large rivers, with S. yahense and S. mengense (occurs only in Cameroon and the Central African Republic and so absent from this study) in smaller rivers and streams. Although Quillévéré et al. (1976, 1977) characterised and compared river features of savanna and forest-dwelling species, there have been few other quantitative studies of the ecological requirements of the different species and none using the multivariate statistical methods applied in this investigation. The results presented here confirmed and quantified niche separations between different Simulium species and, in particular, those for the S. damnosum complex.

Results of the CCA for the S. damnosum complex (Fig. 3) revealed clear separations in particular for S. sanctipauli s.l. and S. yahense from the others, which in turn were split along a hydrological gradient reflecting their known ecological adaptations to rivers of different discharges and widths with temperature, for instance, defining S. yahense preferences. Ya'cob et al. (2016b) also found temperature, river width and discharge to be dominant in their CCAs.

S. yahense was found in rivers with a mean water temperature of $24.16^{\circ} \mathrm{C}$, nearly 2 degrees lower than the mean (27.65) for S. sanctipauli s.1., while the other species were all found in rivers with means of $>28^{\circ} \mathrm{C}$ (Table 2). These data add to and complement river temperature ranges for different members of the $S$. damnosum complex, with only a few mean values, 
listed by Cheke (2012). It was not surprising that the Liberian S. sanctipauli s.l. was separated according to river discharge (mean $58.83 \mathrm{~m}^{3} \cdot \mathrm{sec}^{-1}$ ) and maximum river width (mean $108.42 \mathrm{~m}$ ) as the sub-complex is well known to occur predominantly in large rivers with substantial flow. Similarly, S. yahense which segregated on a temperature axis (see above) with slope (highest mean score of 4.09) also important, is a species of relatively cool narrow rivers (mean maximum width only $23.1 \mathrm{~m}$ ) in upland, well forested, areas and was the most likely to be found in rocky rapids (river features score the highest at 4.56). The highland habitat of $S$. squamosum was confirmed by its having the highest mean value for altitude (mean $293.75 \mathrm{~m})$, with $S$. sanctipauli s.1. the lowest (127.5m).

Of the non-vector species, the highland-dwelling $S$. futaense was found in the highest (mean altitude $414 \mathrm{~m}$ ) and coldest rivers (mean $21.66^{\circ} \mathrm{C}$ ) and $S$. ruficorne in the hottest (29.25 C). Simulium species most often found associated with members of the $S$. damnosum complex were $S$. unicornutum, S. cervicornutum, $S$. adersi, $S$. tridens, $S$. kenyae and $S$. hargreavesi (Fig. 1B) and these species were separated along the CCA2 axis dominated by river features and to a lesser extent along the CCA2 axis dominated by temperature (Fig. 4B), possibly reflecting their associations with different members of the vector complex.

The data were not all collected at the same time of the day so, given that river water temperatures in the region may vary by about $2^{\circ} \mathrm{C}$ during the course of a day (see Fig. 10 of Garms et al. 1991), some inaccuracy is introduced by the lack of temporal constancy. In addition many variables, notably $\mathrm{pH}$, dissolved oxygen concentration and conductivity, were omitted from our study, although data on hardness and carbon dioxide concentrations for some polluted and unpolluted rivers in Liberia are given by Garms et al. (1991). Previous studies (Quillévéré et al., 1976, 1977; Millest et al., 1999) have highlighted the importance of 
$\mathrm{pH}$ but they relied on $\mathrm{pH}$ papers for their tests prior to the wide availability of electronic $\mathrm{pH}$ meters, so the accuracy of their results may not be reliable. Nevertheless, more recent studies using modern $\mathrm{pH}$ meters have also drawn attention to the importance of $\mathrm{pH}$ (Srisuka et al., 2015; Ya'cob et al., 2016a), so it is worth noting that the pH of the St.Paul river at Haindi, a major breeding site for the St.Paul form of S. soubrense, ranged from 6.9 to 7.7 between September 1967 and June 1968, when dissolved oxygen concentrations ranged from 8.3 to 10.5 mg. $1^{-1}$ (Bong Mining Company, unpublished data). Details of physicochemical characteristics of the River Pra in Ghana, another breeding site for S. sanctipauli s.l., were published by Wilson et al. (2005).

The summaries of environmental data according to species (Tables $2 \& 3$ ) provide quantitative support for the qualitative summaries given for the Simuliidae of Guinea, most of which species also occur in Liberia, by Garms \& Post (1967) who provided diagrams of the species' preferred river types and species' associations.

Cheke et al. (2015) used temperature data in mathematical models to predict how populations of savanna-dwelling $S$. damnosum / S. sirbanum and forest-dwelling $S$. sanctipauli in Ghana and Liberia, respectively, might change with increasing temperatures under climate change predictions and their likely consequences for future onchocerciasis transmission scenarios. The temperature data provided in this paper for additional members of the $S$. damnosum complex may allow similar predictions to be made for extra vector species and, also, on how they might interact competitively in the future. The data presented may also assist in identifying which vector or vectors are present at breeding sites in the absence of cytotaxonomic data, and in more general ecological predictions for West African riverine ecosystems. 


\section{Acknowledgements}

The studies in Liberia were part of an onchocerciasis research project conducted by the former Liberia Research Unit of the Bernhard Nocht Institute for Tropical Medicine, Hamburg (1967 to 1990) located on the concession area of the Bong Mining Company in Bong County. We are particularly indebted to the field team of the unit, in particular to the late Mr. Shakespeare Doe-Williams, who guided most of the field trips using his very good knowledge of the country, and to Richard Bouye for much assistance in the field. We also thank the many staff members of the Bernhard Nocht Institute, which funded the research in Liberia, for their help. The data from Benin, Ghana and Togo were collected while RAC and RG were consultants for the WHO Onchocerciasis Control Programme (OCP), when field assistance from the late Magdalene Kerner was much appreciated, as was the help provided by numerous OCP staff members and the pilots of Viking Helicopters.

\section{References}

Adler, P, Crosskey, R.W., 2016. World blackflies (Diptera: Simuliidae): a comprehensive revision of the taxonomic and geographical inventory [2016]. http://www.clemson.edu/ cafls/biomia/pdfs/blackflyinventory.pdf.

Chaoui Boudghane-Bendiouis, C., Abdellaoui-Hassaïne, K., Belqat, B., Franquet, E., Boukli Hacene, S., Yadi, B., 2014. Habitat characterization of black flies (Diptera: Simuliidae) in the Tafna catchment of western Algeria. Open Journal of Ecology 4, 1014-1024. 
Cheke, R.A., 2012. The thermal constant of the onchocerciasis vector Simulium damnosum s.1. in West Africa. Medical and Veterinary Entomology 26, 236-238.

Cheke, R.A., Basáñez, M.-G., Perry, M., White, M.T., Garms, R., Obuobie, E., Lamberton, P.H.L., Young, S., Osei-Atweneboana, M.Y., Intsiful, J., Shen, M., Boakye, D.A. \& Wilson, M.D., 2015. Potential effects of warmer worms and vectors on onchocerciasis transmission in West Africa. Philosophical Transactions of the Royal Society B. 370, 20130559.

Cheke, R.A., Fiasorgbor, G.K., Walsh, J.F., Yameogo, L., 2008. Elimination of the Djodji form of the blackfly Simulium sanctipauli sensu stricto as a result of larviciding by the WHO Onchocerciasis Control Programme in West Africa. Medical and Veterinary Entomology 22, 172-174.

Cheke, R.A., Garms, R., 1983. Reinfestations of the southeastern flank of the Onchocerciasis Control Programme area by windborne vectors. Philosophical Transactions of the Royal Society of London series B 302, 471-484.

Cheke, R.A., Garms, R., Ouedraogo, J., Some, A., Sowah, S., 1987. The Beffa form of Simulium soubrense of the S. damnosum complex in Togo and Benin. Medical and Veterinary Entomology 1, 29-35.

Couceiro, S.R.M., Hamada, N., Sagot, L.B., Pepinelli, M., 2014. Black-fly assemblage distribution patterns in streams in disturbed areas in southern Brazil. Acta Tropica 140, 26-33.

Garms, R., 1974. Über die Verbreitung und Ökologie der Kriebelmücken (Simuliidae) in Liberia. Zeitschrift für Angewandte Zoologie 61, 63-90. 
Garms, R., Cheke, R.A., Vajime, C.G., Sowah, S., 1982. The occurrence and movements of different members of the Simulium damnosum complex in Togo and Benin. Zeitschrift für Angewandte Zoologie 69, 219-236.

Garms, R., Cheke, R.A., 1985. Infections with Onchocerca volvulus in different members of the Simulium damnosum complex in Togo and Benin. Zeitschrift für Angewandte Zoologie $72,479-495$.

Garms, R., Cheke, R.A., Fiasorgbor, G.K.,Walsh, J.F., 1989. Seasonal extension of the breeding range of Simulium sanctipauli from forest into savanna in eastern Ghana and Togo. Zeitschrift für Angewandte Zoologie 76, 457-467.

Garms, R., Cheke, R. A., Sachs, R., 1991. A temporary focus of savanna species of the Simulium damnosum complex in the forest zone of Liberia. Tropical Medicine and Parasitology 42: 181-187.

Garms, R., Post, A., 1967. Die Simulien der Republik Guinea, Westafrika. Internationale Revue der gesamten Hydrobiologie 52, 1-36.

Garms, R., Vajime, C.G., 1975. On the ecology and distribution of the species of the Simulium damnosum complex in different bioclimatic zones of Liberia and Guinea. Tropenmedizin und Parasitologie 26, 375-380.

Güzelhan, C., Garms, R. 1991. Cytogenetic comparison of Simulium soubrense populations in Liberia (Simuliidae, Diptera). Zeitschrift für Angewandte Zoologie 78, 179-187

Legendre, P., Legendre, L., 1998. Numerical Ecology. Second edition. Elsevier Science BV, Amsterdam, The Netherlands.

McCall, P.J., 1995. Oviposition aggregation pheromone in the Simulium damnosum complex. Medical and Veterinary Entomology 9, 101-108. 
McCall, P.J., Heath, R.R., Dueben, B.D., Wilson, M.D. 1997. Oviposition pheromone in the Simulium damnosum complex: biological activity of chemical fractions from gravid ovaries. Physiological Entomology 22, 224-230.

Millest, A. L., Cheke, R. A., Greenwood, R., 1999. Distribution of the Simulium metallicum complex in Mexico in relation to selected environmental variables. Medical and Veterinary Entomology 13, 139-149.

Oksanen, J., Blanchet, F.G., Friendly, M., Kindt, R., Legendre, P., McGlinn, D., Minchin, P.R., O'Hara, R.B., Simpson, G.L., Solymos, P., Stevens, M.H.H., Szoecs, E., Wagner, H. 2016. Vegan: Community Ecology Package. R package version 2.4-0. https://CRAN.Rproject.org/package=vegan .

Quillévéré, D., Gouzy, M., Séchan, Y., Pendriez, B., 1976. Etude du complexe Simulium damnosum en Afrique de l'Ouest. IV. Analyse de l'eau des gites larvaires en saison sèche. Cahiers ORSTOM Série Entomologie, Médicale et Parasitologie 14, 315-330.

Quillévéré, D., Gouzy, M., Séchan, Y., Pendriez, B., 1977. Etude du complexe Simulium damnosum en Afrique de l'Ouest. VI. Analyse de l'eau des gites larvaires en saison des pluies; comparaison avec la saison sèche. Cahiers ORSTOM Série Entomologie, Médicale et Parasitologie 15, 195-207.

Post, R.J., 1986. The cytotaxonomy of Simulium sanctipauli and Simulium soubrense (Diptera: Simuliidae). Genetica 69, 191-207.

R Core Team, 2014. R: a language and environment for statistical computing. R Foundation for Statistical Computing, Vienna, Austria. http://www.R-project.org/.

Srisuka, W., Takaoka, H., Otsuka, Y., Fukuda, W., Thongsahuan, S., Taa, K., Choochote, W., Saeung, A., 2015. Seasonal biodiversity of black flies (Diptera: Simuliidae) and evaluation 
of ecological factors influencing species distribution at Doi Pha Hom Pok National Park, Thailand. Acta Tropica 149: 212-219.

Ter Braak, C.J.F.,1986. Canonical correspondence analysis: a new eigenvector technique for multivariate direct gradient analysis. Ecology, 67, 1167-1179.

Vajime, C.G., Dunbar, R.W., 1975. Chromosomal identification of eight species of the subgenus Edwardsellum near and including Simulium (Edwardsellum) damnosum Theobald (Diptera: Simuliidae). Tropenmedizin und Parasitologie 26, 111-138.

Wilson, M. D., Akpabey, F. J., Osei-Atweneboana, M. Y., Boakye, D. A., Ocran, M., Kurtak, D. C., Cheke, R. A., Mensah, G. E., Birkhold, D., Cibulsky, R., 2005. Field and laboratory studies on water conditions affecting the potency of VectoBac ${ }^{\circledR}$ (Bacillus thuringiensis serotype H-14) against larvae of the blackfly, Simulium damnosum. Medical and Veterinary Entomology 19: 404-412.

Ya'cob, Z., Takaoka, H., Pramual, P., Low, V.L., Sofian-Azirun, M., 2016a. Breeding habitat preference of preimaginal black flies (Diptera:Simuliidae) in Peninsular Malaysia. Acta Tropica 153, 57-63.

Ya'cob, Z., Takaoka, H., Pramual, P., Low, V.L, Sofian-Azirun, M., 2016b. Distribution pattern of black fly (Diptera: Simuliidae) assemblages along an altitudinal gradient in Peninsular Malaysia. Parasites \& Vectors 9, 219. DOI 10.1186/s13071-016-1492-7. 
Table 1. Details of measurements made at Simulium spp. breeding sites and of subjective assessments of habitat characteristics.






\begin{tabular}{|l|l|l|l|l|l|l|}
\hline Terrain & Plain & Hilly & Mountainous & & & \\
\hline Supports & Stones or rocks & Dead leaves & Sticks or roots & $\begin{array}{l}\text { Trailing } \\
\text { grasses or } \\
\text { plants }\end{array}$ & Bushes & \\
\hline
\end{tabular}


Table 2. Mean values of measured environmental variables according to Simulium taxon. Figures in parentheses are standard errors of the mean (SEM).

\begin{tabular}{|c|c|c|c|c|c|c|}
\hline Simulium taxon & $\begin{array}{l}\text { River } \\
\text { width } \\
(\max )(\mathrm{m})\end{array}$ & $\begin{array}{l}\text { Water Temp. } \\
\left({ }^{\circ} \mathrm{C}\right)\end{array}$ & $\begin{array}{l}\text { Air } \\
\text { Temp } \\
\text { Wet }\left({ }^{\circ} \mathrm{C}\right)\end{array}$ & $\begin{array}{l}\text { Air } \\
\text { Temp } \\
\text { Dry } \\
\left({ }^{\circ} \mathrm{C}\right)\end{array}$ & RH (\%) & $\begin{array}{l}\text { Altitude } \\
\text { (m) }\end{array}$ \\
\hline damnosum s.l. & $52.87(3.85)$ & $26.35(0.16)$ & $24.17(0.15)$ & $27.78(0.20)$ & $84.62(1.12)$ & $234.57(13.73)$ \\
\hline sanctipauli s.l. & $108.42(8.62)$ & $27.65(0.23)$ & $25.09(0.41)$ & $28.72(0.34)$ & $82.18(2.48)$ & $127.50(22.36)$ \\
\hline $\begin{array}{l}\text { damnosum } \\
\text { s.str. }\end{array}$ & $59.37(6.03)$ & $28.39(0.22)$ & $23.00(-)$ & $29.58(0.30)$ & $86.00(-)$ & $254.29(22.66)$ \\
\hline sirbanum & $78.89(14.21)$ & $28.13(0.33)$ & - & $29.53(0.42)$ & - & $250.00(-)$ \\
\hline squamosum & $32.02(3.03)$ & $28.05(0.29)$ & - & $29.71(0.30)$ & - & $293.75(35.70)$ \\
\hline yahense & $23.10(2.99)$ & $24.16(0.16)$ & $24.01(0.16)$ & $26.15(0.24)$ & $86.08(1.26)$ & $253.32(17.61)$ \\
\hline sancti.Djodji & $33.25(11.21)$ & $28.47(0.66)$ & - & $29.86(0.90)$ & - & - \\
\hline $\begin{array}{l}\text { soubrense } \\
\text { Beffa }\end{array}$ & $80.46(10.46)$ & $28.27(0.27)$ & - & $29.24(0.45)$ & - & $240.00(60.00)$ \\
\hline alcocki & $4.87(0.65)$ & $24.38(0.25)$ & $24.01(0.34)$ & $25.35(0.44)$ & $91.84(1.55)$ & $217.08(37.31)$ \\
\hline garmsi & $18.30(3.86)$ & $24.27(0.14)$ & $24.44(0.17)$ & $26.07(0.24)$ & $89.04(1.10)$ & $174.79(13.12)$ \\
\hline djallonense & 7.67 (1.52) & $23.96(0.19)$ & $24.49(0.19)$ & $25.83(0.31)$ & $91.42(1.22)$ & $237.05(31.50)$ \\
\hline liberiense & $9.11(1.74)$ & $23.69(0.19)$ & $24.37(0.34)$ & $25.27(0.43)$ & $93.66(1.18)$ & $207.58(23.17)$ \\
\hline schoutedeni & $20.53(2.13)$ & $24.21(0.12)$ & $24.22(0.14)$ & $26.08(0.20)$ & $87.56(1.04)$ & $185.45(12.84)$ \\
\hline cervicornutum & $15.54(1.07)$ & $24.47(0.14)$ & $24.28(0.15)$ & $26.30(0.22)$ & $87.52(1.12)$ & $198.98(14.18)$ \\
\hline unicornutum & $25.78(3.49)$ & $24.72(0.14)$ & $24.28(0.13)$ & $26.46(0.20)$ & $88.06(0.88)$ & $197.36(11.32)$ \\
\hline blacklocki & $7.38(1.92)$ & $24.41(0.20)$ & $25.24(0.41)$ & $27.17(0.61)$ & $87.17(2.52)$ & $110.00(14.51)$ \\
\hline kenyae & $84.25(9.36)$ & $25.24(0.29)$ & $23.88(0.23)$ & $26.47(0.34)$ & $84.55(1.57)$ & $219.22(22.62)$ \\
\hline ruficorne & $8.00(2.00)$ & $29.25(0.75)$ & - & - & - & - \\
\hline manense & $9.50(0.50)$ & $24.17(0.41)$ & $23.67(0.88)$ & $25.13(0.19)$ & $90.67(4.91)$ & $196.67(27.28)$ \\
\hline loutetense & $6.77(1.01)$ & $23.96(0.16)$ & $24.16(0.17)$ & $25.66(0.23)$ & $90.17(1.07)$ & $248.63(19.42)$ \\
\hline colasbelcouri & $5.17(1.28)$ & $23.21(0.90)$ & $23.87(0.99)$ & $25.23(0.30)$ & $90.67(5.40)$ & $241.67(30.81)$ \\
\hline futaense & $21.00(9.00)$ & $21.66(1.10)$ & $21.62(1.13)$ & $23.40(1.04)$ & $88.20(6.36)$ & $414.00(17.49)$ \\
\hline ovazzae & $14.33(3.50)$ & $22.82(0.58)$ & $23.58(0.53)$ & $25.46(0.70)$ & $87.55(3.84)$ & $370.00(44.66)$ \\
\hline berneri & $35.83(6.64)$ & $24.51(0.69)$ & $24.12(0.41)$ & $26.14(0.96)$ & $88.11(5.91)$ & $357.14(43.08)$ \\
\hline lumbwanum & $30.00(-)$ & $24.35(1.15)$ & $24.00(-)$ & $24.80(-)$ & $95.00(-)$ & $50.00(-)$ \\
\hline johannae & $22.40(7.95)$ & $23.53(0.54)$ & $23.92(0.85)$ & $25.02(0.93)$ & $92.83(1.60)$ & $201.67(64.16)$ \\
\hline tridens & $124.00(46.65)$ & $27.14(1.75)$ & $27.00(-)$ & $30.67(1.88)$ & $60.00(-)$ & $10.00(-)$ \\
\hline adersi & $48.70(5.54)$ & $28.50(0.23)$ & $24.00(-)$ & $29.88(0.29)$ & $62.00(-)$ & $210.00(10.00)$ \\
\hline hargreavesi & $23.42(4.36)$ & $27.60(0.39)$ & - & $29.16(0.63)$ & - & - \\
\hline bovis & $50.00(30.00)$ & $26.25(1.25)$ & - & - & - & - \\
\hline
\end{tabular}




\begin{tabular}{|c|c|c|c|c|c|c|c|c|c|c|c|c|c|c|c|}
\hline $\begin{array}{l}\text { Simulium } \\
\text { taxon }\end{array}$ & $\begin{array}{l}\text { Type } \\
\text { of } \\
\text { Wate } \\
r\end{array}$ & $\begin{array}{l}\text { Wate } \\
r \\
\text { Leve } \\
l\end{array}$ & $\begin{array}{l}\text { River } \\
\text { Bed }\end{array}$ & $\begin{array}{l}\text { River } \\
\text { Feat } \\
- \\
\text { ures }\end{array}$ & $\begin{array}{l}\text { Slop } \\
\text { e }\end{array}$ & $\begin{array}{l}\text { Heig } \\
\text { ht } \\
\text { of } \\
\text { wate } \\
\text { r- } \\
\text { fall } \\
\text { (m) }\end{array}$ & $\begin{array}{l}\text { Curr } \\
\text { ent }\end{array}$ & $\begin{array}{l}\text { Vege } \\
\text { t- } \\
\text { ation }\end{array}$ & Light & $\begin{array}{l}\text { Dept } \\
\text { h } \\
(\mathrm{cm})\end{array}$ & $\begin{array}{l}\text { Disc } \\
\text { harg } \\
\text { e } \\
\text { M3/ } \\
\text { sec }\end{array}$ & $\begin{array}{l}\text { Leng } \\
\text { th } \\
\text { of } \\
\text { Bree } \\
\text { d- } \\
\text { ing } \\
\text { Area } \\
\text { (m) }\end{array}$ & $\begin{array}{l}\text { Envir } \\
\text {-ons }\end{array}$ & $\begin{array}{l}\text { Terr- } \\
\text { ain }\end{array}$ & $\begin{array}{l}\text { Supp } \\
\text {-orts }\end{array}$ \\
\hline $\begin{array}{l}\text { Sd sensu } \\
\text { lato }\end{array}$ & 3.22 & 2.57 & 1.36 & 3.89 & 3.32 & 3.34 & 3.56 & 2.44 & 2.34 & $\begin{array}{l}38.6 \\
9\end{array}$ & $\begin{array}{l}15.6 \\
5\end{array}$ & $\begin{array}{l}82.1 \\
4\end{array}$ & 3.04 & 1.45 & 3.51 \\
\hline $\begin{array}{l}\text { sanctipau } \\
\text { li s.l. }\end{array}$ & 4.20 & 2.86 & 1.20 & 3.83 & 2.85 & 2.50 & 3.76 & 2.82 & 2.82 & $\begin{array}{l}40.0 \\
3\end{array}$ & $\begin{array}{l}58.8 \\
3\end{array}$ & $\begin{array}{l}124 . \\
73\end{array}$ & 3.09 & 1.22 & 3.71 \\
\hline $\begin{array}{l}\text { damnosu } \\
m \text { s.str. }\end{array}$ & 3.64 & 2.54 & 1.36 & 3.89 & 2.78 & 2.02 & 4.00 & 3.04 & & $\begin{array}{l}26.1 \\
9\end{array}$ & 1.37 & $\begin{array}{l}105 . \\
36\end{array}$ & 2.95 & 1.14 & 3.92 \\
\hline sirbanum & 3.76 & 2.34 & 1.14 & 3.88 & 3.00 & 2.40 & & 3.28 & & 0.75 & 3.79 & $\begin{array}{l}107 . \\
10\end{array}$ & 3.07 & 1.00 & 3.85 \\
\hline $\begin{array}{l}\text { squamosu } \\
m\end{array}$ & 3.17 & 2.51 & 1.58 & 3.89 & 2.83 & 2.00 & & 2.84 & & $\begin{array}{l}33.1 \\
0\end{array}$ & 1.79 & $\begin{array}{l}84.6 \\
9\end{array}$ & 3.08 & 1.63 & 3.82 \\
\hline yahense & 2.50 & 2.43 & 1.26 & 4.56 & 4.09 & 3.70 & 3.55 & 1.84 & 2.25 & $\begin{array}{l}43.0 \\
9\end{array}$ & 1.43 & $\begin{array}{l}58.6 \\
1\end{array}$ & 2.89 & 1.52 & 3.20 \\
\hline $\begin{array}{l}\text { sancti } \\
\text { Djodji }\end{array}$ & 3.50 & 2.63 & 1.00 & 3.38 & 2.25 & & & 1.50 & & & 1.06 & $\begin{array}{l}76.6 \\
7\end{array}$ & 3.50 & 1.86 & 3.86 \\
\hline $\begin{array}{l}\text { soubr } \\
\text { Beffa }\end{array}$ & 3.92 & 2.63 & 1.23 & 3.88 & 2.75 & 2.50 & & 3.27 & & $\begin{array}{l}35.0 \\
5\end{array}$ & 1.48 & $\begin{array}{l}146 . \\
56\end{array}$ & 3.00 & 1.05 & 4.00 \\
\hline alcocki & 2.00 & 1.36 & 1.66 & 5.00 & 3.92 & 2.25 & 3.22 & 1.94 & 1.93 & $\begin{array}{l}20.8 \\
5\end{array}$ & 2.03 & $\begin{array}{l}30.6 \\
1\end{array}$ & 2.50 & 1.69 & 4.00 \\
\hline garmsi & 2.40 & 2.29 & 1.41 & 2.00 & 3.64 & 4.53 & 3.25 & 1.80 & 2.33 & $\begin{array}{l}43.0 \\
4\end{array}$ & 1.56 & $\begin{array}{l}34.1 \\
7\end{array}$ & 3.16 & 1.29 & 2.96 \\
\hline $\begin{array}{l}\text { djallonen } \\
\text { se }\end{array}$ & 2.09 & 1.56 & 1.45 & 5.00 & 4.25 & 9.82 & 3.21 & 1.67 & 1.60 & $\begin{array}{l}28.0 \\
0\end{array}$ & 1.44 & $\begin{array}{l}47.3 \\
6\end{array}$ & 3.56 & 1.84 & 2.95 \\
\hline $\begin{array}{l}\text { liberiens } \\
e\end{array}$ & 2.07 & 2.00 & 1.47 & 5.00 & 4.23 & 2.41 & 3.32 & 1.87 & 1.90 & $\begin{array}{l}33.0 \\
0\end{array}$ & 0.51 & $\begin{array}{l}47.0 \\
6\end{array}$ & 3.95 & 1.56 & 3.24 \\
\hline $\begin{array}{l}\text { schouted } \\
\text { eni }\end{array}$ & 2.58 & 2.59 & 1.46 & 4.33 & 3.51 & 5.49 & 3.35 & 1.91 & 2.38 & $\begin{array}{l}43.4 \\
2\end{array}$ & 1.77 & $\begin{array}{l}41.0 \\
9\end{array}$ & 3.18 & 1.32 & 3.00 \\
\hline $\begin{array}{l}\text { cervicorn } \\
\text { utum }\end{array}$ & 2.42 & 2.34 & 1.43 & 4.28 & 3.56 & 6.32 & 3.40 & 2.05 & 2.31 & $\begin{array}{l}39.7 \\
9\end{array}$ & 1.56 & $\begin{array}{l}47.7 \\
3\end{array}$ & 3.07 & 1.52 & 3.30 \\
\hline $\begin{array}{l}\text { unicornut } \\
\text { um }\end{array}$ & 2.57 & 2.36 & 1.54 & 4.14 & 3.55 & 3.65 & 3.28 & 2.01 & 2.21 & $\begin{array}{l}38.5 \\
7\end{array}$ & 1.99 & $\begin{array}{l}47.7 \\
5\end{array}$ & 3.12 & 1.39 & 3.14 \\
\hline $\begin{array}{l}\text { blacklock } \\
i\end{array}$ & 2.00 & 2.38 & 2.33 & 5.00 & 3.46 & $\begin{array}{l}13.1 \\
3\end{array}$ & 3.08 & 2.69 & 2.60 & $\begin{array}{l}35.7 \\
1\end{array}$ & 0.05 & $\begin{array}{l}25.5 \\
6\end{array}$ & 3.63 & 1.38 & 3.54 \\
\hline kenyae & 3.94 & 2.91 & 1.18 & 4.11 & 3.66 & 6.36 & 3.62 & 1.79 & 2.64 & $\begin{array}{l}38.1 \\
9\end{array}$ & 3.55 & $\begin{array}{l}87.8 \\
9\end{array}$ & 3.22 & 1.36 & 2.96 \\
\hline ruficorne & 2.00 & 2.50 & 1.50 & 5.00 & 3.00 & & & 3.00 & & & & 2.00 & 2.00 & 2.00 & 4.00 \\
\hline manense & 1.67 & 2.00 & 1.00 & & 5.00 & $\begin{array}{l}20.5 \\
0\end{array}$ & 4.00 & 1.00 & 1.00 & $\begin{array}{l}50.0 \\
0\end{array}$ & 0.01 & $\begin{array}{l}25.0 \\
0\end{array}$ & 5.00 & 2.50 & 2.00 \\
\hline $\begin{array}{l}\text { loutetens } \\
e\end{array}$ & 2.02 & 1.68 & 1.24 & 5.00 & 4.60 & 5.68 & 3.37 & 1.58 & 1.63 & $\begin{array}{l}34.0 \\
0\end{array}$ & 2.26 & $\begin{array}{l}31.5 \\
3\end{array}$ & 3.53 & 1.77 & 2.81 \\
\hline $\begin{array}{l}\text { colasbelc } \\
\text { ouri }\end{array}$ & 2.00 & 1.67 & 1.00 & & 5.00 & 5.33 & 4.00 & 1.00 & 1.75 & $\begin{array}{l}50.0 \\
0\end{array}$ & 1.68 & $\begin{array}{l}21.6 \\
7\end{array}$ & 5.00 & 2.00 & 2.14 \\
\hline
\end{tabular}




\begin{tabular}{|c|c|c|c|c|c|c|c|c|c|c|c|c|c|c|c|}
\hline futaense & 1.67 & 2.50 & 1.00 & & 5.00 & $\begin{array}{l}17.5 \\
0\end{array}$ & 4.33 & 1.00 & 1.50 & & 0.35 & $\begin{array}{l}100 . \\
00\end{array}$ & 4.50 & 2.00 & 3.00 \\
\hline ovazzae & 1.89 & 2.25 & 1.44 & & 4.38 & 7.50 & 3.50 & 1.25 & 2.00 & $\begin{array}{l}50.0 \\
0\end{array}$ & 0.25 & $\begin{array}{l}112 . \\
86\end{array}$ & 2.83 & 2.00 & 2.88 \\
\hline berneri & 2.88 & 2.86 & 1.38 & & 4.43 & 6.00 & 3.86 & 1.17 & 2.33 & & 1.52 & $\begin{array}{l}64.1 \\
7\end{array}$ & 3.17 & 1.50 & 2.86 \\
\hline $\begin{array}{l}\text { lumbwan } \\
\text { um }\end{array}$ & 3.00 & & 1.50 & & 5.00 & & 3.50 & 1.00 & 2.00 & & 2.00 & $\begin{array}{l}100 . \\
00\end{array}$ & & & 3.00 \\
\hline johannae & 1.80 & 2.33 & 1.60 & & 4.00 & 8.50 & 3.80 & 2.80 & & $\begin{array}{l}20.0 \\
0\end{array}$ & 0.22 & $\begin{array}{l}53.0 \\
0\end{array}$ & 3.20 & 1.25 & 4.00 \\
\hline tridens & 4.80 & 2.80 & 1.60 & 3.25 & 2.60 & & 3.00 & 2.80 & & & 0.05 & $\begin{array}{l}116 . \\
67\end{array}$ & 3.00 & 1.00 & 3.60 \\
\hline adersi & 3.51 & 2.32 & 1.37 & 3.88 & 2.65 & 0.77 & 3.00 & 2.87 & & $\begin{array}{l}12.0 \\
9\end{array}$ & 2.12 & $\begin{array}{l}89.1 \\
7\end{array}$ & 3.01 & 1.27 & 3.76 \\
\hline $\begin{array}{l}\text { hargreav } \\
\text { esi }\end{array}$ & 2.72 & 2.40 & 1.61 & 4.09 & 3.28 & 3.25 & & 3.04 & & 0.53 & 3.75 & $\begin{array}{l}45.4 \\
2\end{array}$ & 3.16 & 1.71 & 3.87 \\
\hline bovis & 4.00 & 3.50 & 1.00 & 4.00 & 3.00 & & & 3.00 & & & & $\begin{array}{l}100 . \\
00\end{array}$ & 2.50 & 1.00 & 4.00 \\
\hline
\end{tabular}

Table 3. Mean values of subjective habitat assessments (1-5 scales in all cases, except 1-3 for light conditions and terrain) according to Simulium taxon. 


\section{Legends for Figures}

Figure 1. (A) Results of cluster analysis of the full data-set $(\mathrm{N}=527)$ with the six clusters used for further analyses highlighted. The "height" refers to the degree of similarity between groupings. (B) Distributions of species according to cluster for the full data-set. The heights of the bars represent the average incidence scores for assigning a species to a particular group.

Figure 2. (A) Ordination diagram for the environmental variables resulting from principal components analysis of the entire data-set. (B) Results of principal components analysis of the six species clusters derived from the complete data-set. The large dots are the centroids (means of the $\mathrm{x}$ and $\mathrm{y}$ values) and the ellipses are $80 \%$ confidence ellipses such that the centroids are $80 \%$ certain to lie within them.

Figure 3. (A) Ordination diagram for the environmental variables resulting from canonical correspondence analysis of the data on different members of the Simulium damnosum complex only $(\mathrm{N}=442)$. (B) Ordination diagram for the onchocerciasis vectors based on canonical correspondence analysis of the different members of the Simulium damnosum complex only.

Figure 4. (A). Ordination diagram for the environmental variables resulting from canonical correspondence analysis of the entire data set but excluding members of the $S$. damnosum complex and six rare species (S. bovis, S. manense, S. colasbelcouri, S. lumbwanum, $S$. blacklocki, S. ruficorne) for which data were insufficient to include in the analysis ( $\mathrm{N}=272)$. (B) Ordination diagram for the species resulting from canonical correspondence analysis of the entire data set but excluding members of the $S$. damnosum complex and six rare species (see under A above). 
Figure 1.
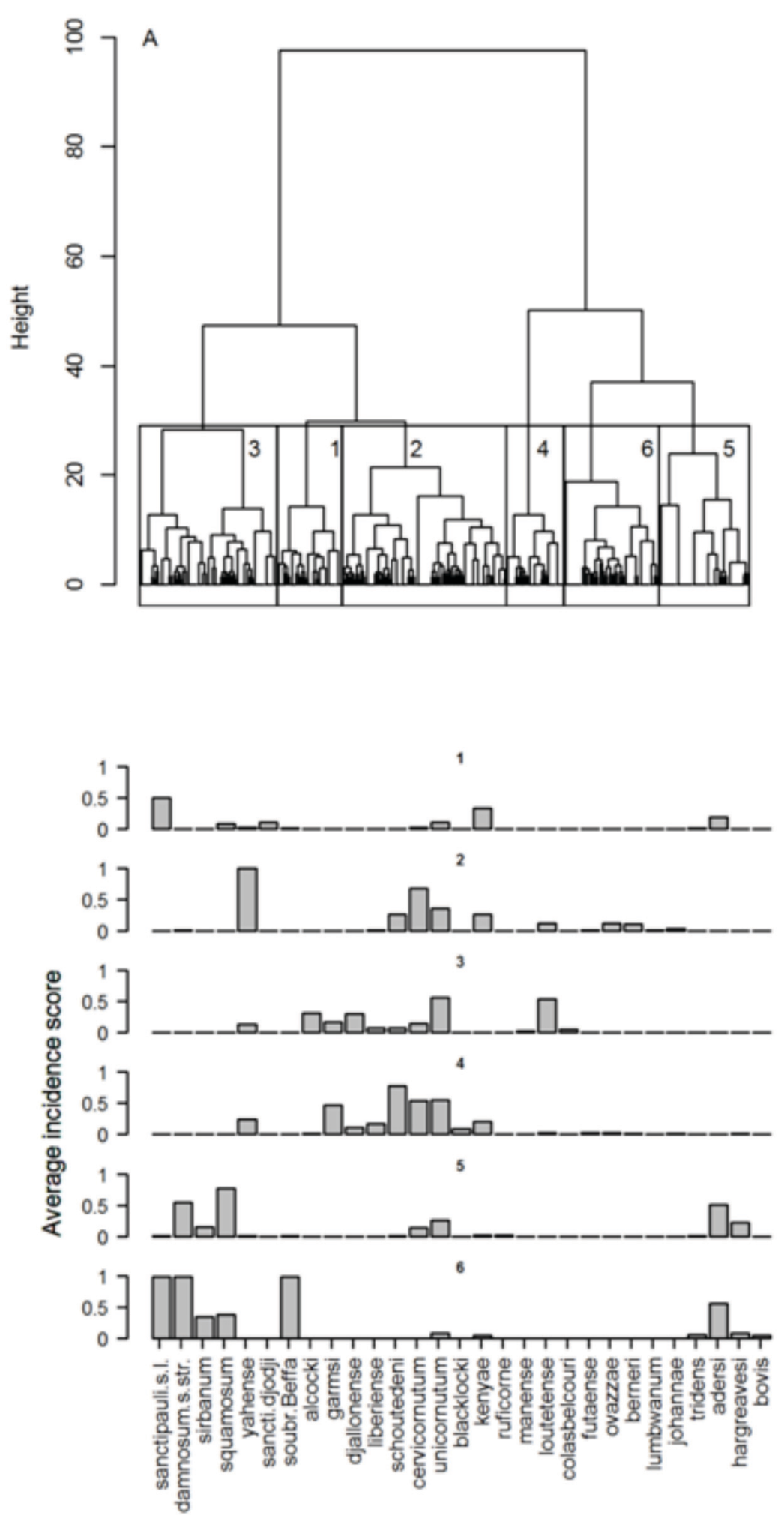
Figure 2.
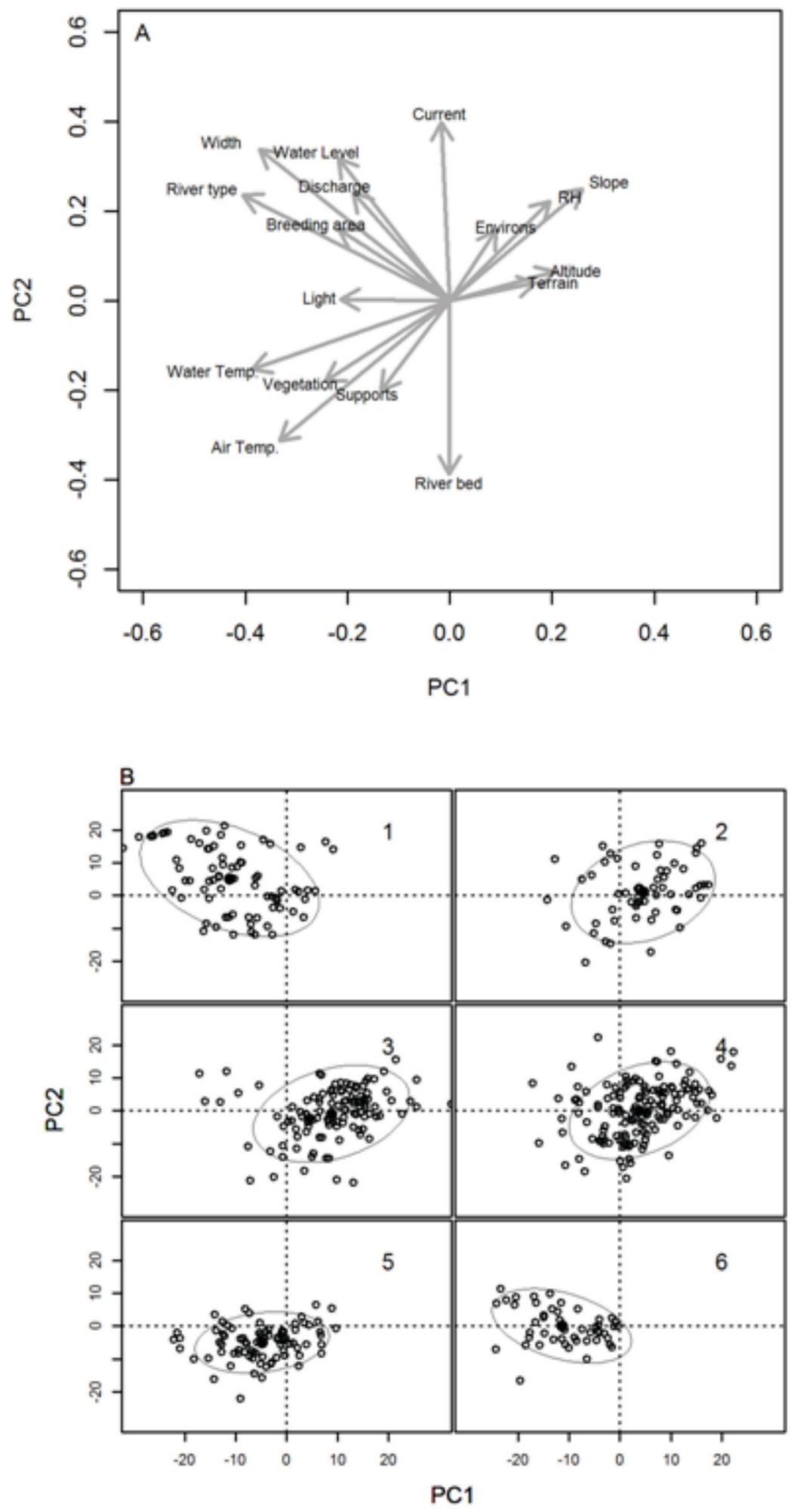
Figure 3.
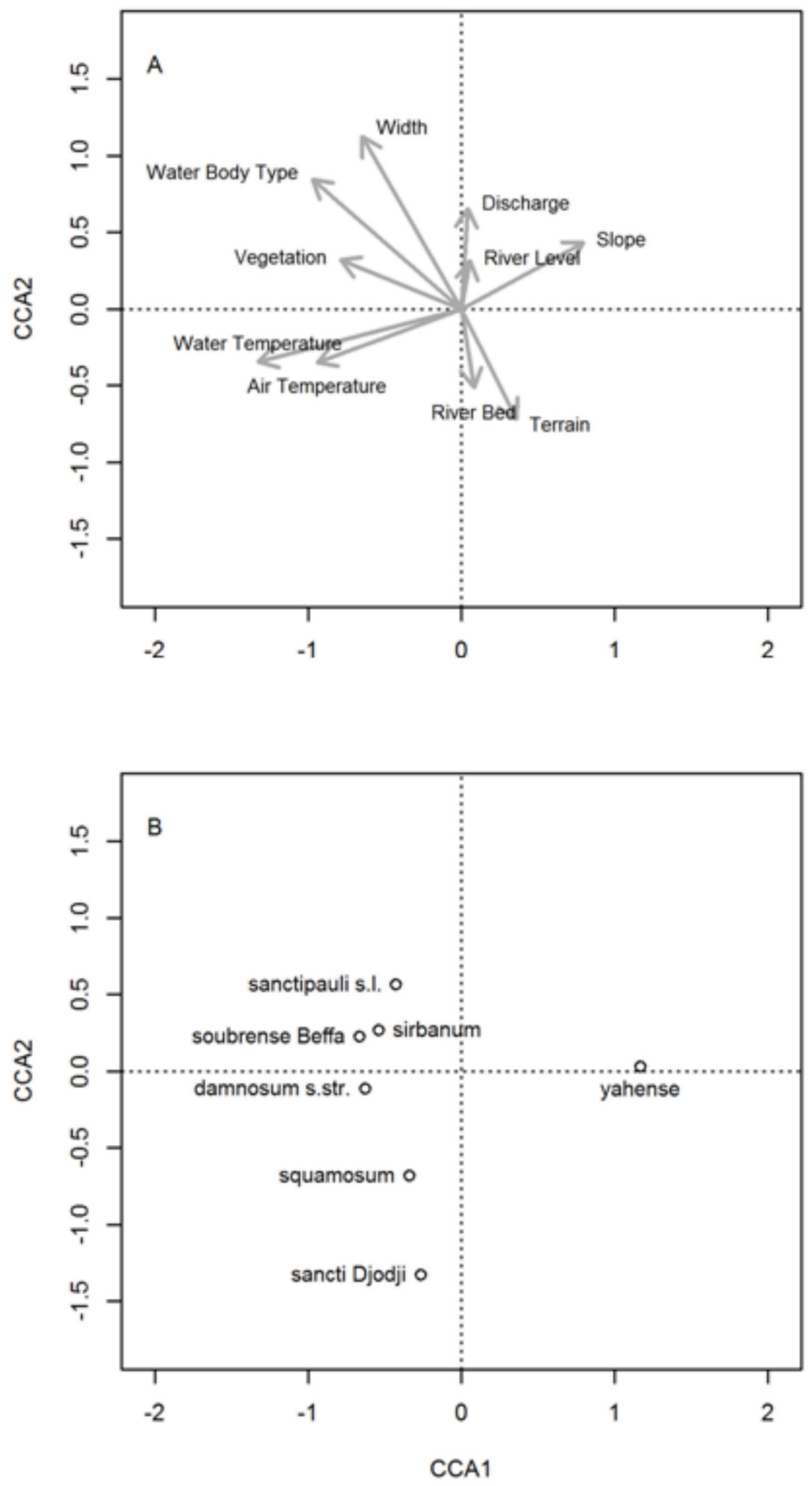
Figure 4.
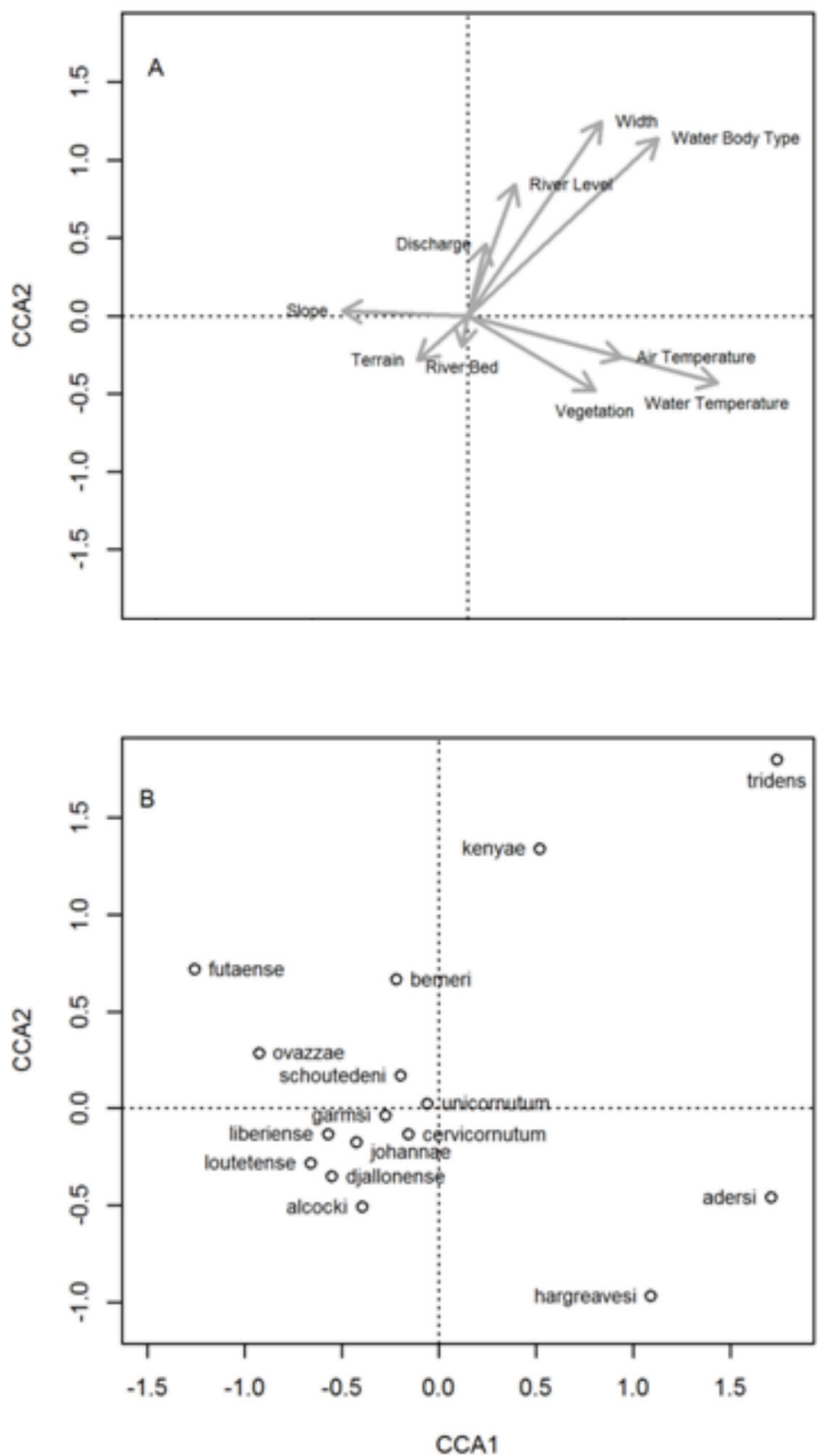